\title{
TRANSAKSI ILEGAL MENGGUNAKAN KARTU ATM MILIK ORANG LAIN
}

\author{
Fina Agustina Suhyana ${ }^{1 *}$, Sigid Suseno ${ }^{2}$, Tasya Safiranita Ramli ${ }^{2}$ \\ ${ }^{1}$ Mahasiswa Fakultas Hukum, Universitas Padjadjaran, Bandung \\ ${ }^{2}$ Dosen Fakultas Hukum, Universitas Padjadjaran, Bandung \\ *Email Korespondensi: finaagustina043@gmail.com
}

\begin{abstract}
Abstrak. Salah satu resiko yang harus disikapi oleh perbankan adalah tindak pidana transaksi ilegal menggunakan kartu ATM milik orang lain, dimana nantinya nasabah tidak mengetahui bahwa saldo di rekeningnya telah habis karena telah terjadi penarikan menggunakan kartu ATM hasil kloning. Oleh karena itu, penelitian ini bertujuan untuk menguraikan penerapan hukum terhadap transaksi illegal menggunakan kartu ATM milik orang lain, dan perlindungan hukum terhadap nasabah sebagai korban tindak pidana transaksi ilegal menggunakan kartu ATM hasil kloning. Penelitian ini menggunakan pendekatan yuridis normatif. Adapun metode analisis dilakukan dengan cara mengidentifikasi secara sistematis, dipolarisasi, dikategorisasi dan dikelompokkan sesuai dengan alur pembahasan dalam penelitian ini. Hasil penelitian menunjukkan bahwa penerapan hukum terhadap transaksi illegal menggunakan kartu ATM milik orang lain, diatur berdasarkan UU No. 1 Tahun 1960 dan UU No. 19 Tahun 2016. Akan tetapi, tindak pidana transaksi illegal menggunakan kartu ATM milik orang lain, belum diatur secara tegas di Indonesia apabila dibandingkan dengan Singapura dan Jepang. Adapun perlindungan hukum terhadap nasabah sebagai korban tindak pidana transaksi ilegal menggunakan kartu ATM hasil kloning, dapat diketahui berdasarkan beberapa peraturan perundang-undangan, antara lain UU No. 21 Tahun 2011, PBI No. 16/1/PBI/2014, POJK No. 1/ POJK.07/2013, serta POJK No. 18/P0JK.07/2018. Dengan dasar kesimpulan tersebut, diharapkan secara tegas dapat dibentuk Undang-Undang tentang tindak pidana transaksi ilegal. Selain itu, Bank selaku PUJK harus membuat kebijakan penggunaan kartu ATM dengan teknologi chip implant, serta penerapan OTP sebagai autentikasi dua faktor (two-factor authentication) kepada para nasabahnya, sehingga risiko tindak pidana transaksi ilegal menggunakan kartu ATM milik orang lain dapat diminimalisir.
\end{abstract}

Kata Kunci: Kartu ATM; Kloning; Perbankan; Teknologi; Transaksi Ilegal.

artikel dengan akses terbuka dibawah lisensi CC BY -4.0

DOI: https://doi.org/10.37276/sjh.v2i2.92 


\section{PENDAHULUAN}

Praktik yang sering dilakukan oleh setiap manusia akan menjadi suatu kebiasaan. Kebiasaan tersebut dapat membentuk norma baru terutama dalam perkembangan arus informasi dengan memanfaatkan jaringan komunikasi dan teknologi. Arus perkembangan teknologi yang pesat mengubah gaya hidup masyarakat di berbagai bidang. Sebagai penggerak utama dalam perkembangan teknologi sangat erat kaitannya dengan jaringan internet. Internet merupakan faktor pendorong utama dalam menjalankan perkembangan teknologi hingga saat ini. Adanya perkembangan teknologi memiliki dampak dan peran yang sangat bermanfaat dan dapat dirasakan secara langsung. Selain itu, setiap negara sejak awal telah siap menghadapi revolusi industri 1.0 hingga revolusi 4.0. Salah satu kesiapan negara adalah dengan membentuk peraturan perundang-undangan untuk melindungi warganya dari kejahatan yang terjadi di dunia virtual. Misalnya perlindungan data, transfer dana elektronik, transaksi elektronik dan hal-hal lain yang masih terkait dalam yurisdiksi virtual. ${ }^{1}$ Adapun peraturan perundang-undangan di Indonesia yang dapat diterapkan untuk menyikapi kejahatan yang terjadi di dunia virtual, antara lain yaitu Undang-Undang Republik Indonesia Nomor 1 Tahun 1960 tentang Perubahan Kitab Undang-Undang Hukum Pidana (selanjutnya disebut UU No. 1 Tahun 1960) dan Undang-Undang Republik Indonesia Nomor 19 Tahun 2016 tentang Perubahan Atas Undang-Undang Nomor 11 Tahun 2008 tentang Informasi dan Transaksi Elektronik (selanjutnya disebut UU No. 19 Tahun 2016).

Kehadiran internet dan revolusi industri 4.0 dapat mengubah pandangan dan pola hidup masyarakat. Salah satunya adalah sektor perbankan memanfaatkan perkembangan teknologi secara wajar untuk memudahkan nasabah dalam melakukan transaksi perbankan. Transaksi di perbankan dengan produk elektronik yang diterbitkan oleh Bank yaitu kartu ATM. ${ }^{2}$

Keberadaan Bank bersumber dari rasa kepercayaan masyarakat untuk melakukan segala jenis layanan perbankan. Perkembangan perbankan harus memperhatikan sistem keamanan pada instrumen yang digunakan sebagai alat pelayanan jasa perbankan. Kehadiran industri 4.0 dalam perbankan diimplementasikan untuk memberikan layanan transaksi melalui perangkat teknologi. Olehnya itu, Bank selaku Pelaku Usaha Jasa Keuangan (PUJK) harus mengetahui kemungkinan risiko yang ada di dunia perbankan. Selain itu, Bank juga harus menjamin sistem keamanan dan memberikan perlindungan hukum kepada nasabahnya. ${ }^{3}$

\footnotetext{
${ }^{1}$ Danrivanto Budhijanto. (2019). Cyberlaw dan Revolusi Industri 4.0. Bandung: Logoz Publishing, hlm. 2-3.

${ }^{2}$ Nevita Sari. (2019). Perlindungan Hukum Bagi Konsumen Nasabah dalam Card Skimming (Studi Kasus Bank BNI Syariah Pusat di Jakarta). Reformasi Hukum, Universitas Islam Jakarta, 23(2), hlm. 151.

${ }^{3}$ Budi Triandi. (2019). Keamanan Informasi Secara Aksiologi dalam Menghadapi Era Revolusi Industri 4.0. JURIKOM (Jurnal Riset Komputer), Universitas Budi Darma, 6(5), hlm. 478.
} 
Salah satu layanan perbankan adalah melakukan transaksi, misalnya melakukan transfer dengan menggunakan produk bank elektronik yaitu kartu ATM sebagai kartu untuk pembayaran baik secara kredit maupun debit. Berdasarkan Pasal 1 butir 3 Peraturan Bank Indonesia Nomor 14/2/PBI/2012 tentang Perubahan Atas Peraturan Bank Indonesia Nomor 11/11/PBI/2009 tentang Penyelenggaraan Kegiatan Alat Pembayaran dengan Menggunakan Kartu, menjelaskan bahwa:

"Alat Pembayaran dengan Menggunakan Kartu, yang selanjutnya disebut APMK, adalah alat pembayaran yang berupa kartu kredit, kartu automated teller machine (ATM) dan/atau kartu debet."

Kartu ATM memiliki sistem keamanan dengan menggunakan personal identification number (PIN), dan hanya nasabah sebagai pemilik kartu ATM yang mengetahui kode keamanan tersebut. Dengan adanya kartu ATM tentunya semakin memudahkan nasabah dalam menyelesaikan transaksi dengan cepat dan dapat dilakukan kapanpun dan dimanapun, tidak perlu datang ke bagian teller lagi untuk melakukan transaksi. Sehingga pihak Bank harus memastikan bahwa kerahasiaan kode pengaman atau kode PIN tidak akan diretas oleh pihak lainnya. ${ }^{4}$

Namun kemudahan bertransaksi perbankan saat ini memiliki dampak dan risiko negatif yang mungkin saja terjadi. Kejahatan yang terjadi dapat berskala transnasional atau bahkan internasional karena kejahatan hanya menggunakan akses jaringan internet. Kejahatan yang terjadi karena perkembangan teknologi akses jaringan internet dikenal dengan cybercrime. ${ }^{5}$

Cybercrime merupakan kejahatan yang lazim, seperti pencurian, penipuan, atau pemalsuan dokumen. Namun perbedaan antara cybercrime dan konvensional terletak pada modus yang digunakan untuk melakukan kejahatan tersebut. Modus cybercrime yang merajalela di sektor perbankan yaitu: skimming, phishing, fraud, pencurian kartu kredit atau kartu debit dengan cara ilegal. Cybercrime merupakan ancaman bagi negara karena bentuk dan akses kejahatan di dunia virtual berkembang pesat. Diperlukan peraturan perundang-undangan yang dapat mengakomodasi segala bentuk cybercrime.

Akhir-akhir ini di Indonesia semakin banyak kasus cybercrime di sektor perbankan. Salah satu bentuk kejahatan dunia virtual di bidang perbankan adalah dengan menggunakan kartu ATM milik orang lain. Kartu ATM hasil kloning digunakan untuk melakukan transaksi seperti pada umumnya. Nasabah sebagai korban tidak dapat mengetahui secara langsung bahwa saldo ATM telah hilang, dicuri oleh pelaku tindak pidana transaksi ilegal. Transaksi ilegal termasuk transaksi keuangan yang mencurigakan.

\footnotetext{
${ }^{4}$ Ni Nyoman Muryatini. (2016). Perlindungan Hukum Bagi Nasabah Pengguna Anjungan Tunai Mandiri (ATM) dalam Sistem Perbankan di Indonesia. Jurnal Magister Hukum Udayana (Udayana Master Law Journal), Universitas Udayana, 5(1), hlm. 121.

${ }^{5}$ Antonius Maria Laot Kian. (2015). Tindak Pidana Credit/Debit Card Fraud dan Penerapan Sanksi Pidananya dalam Hukum Pidana Indonesia. Hasanuddin Law Review (e-Journal), Universitas Hasanuddin, 1(1), hlm. 48.
} 
Lebih lanjut, Bank sebagai institusi dalam menjalankan kegiatan usahanya dilandasi oleh kepercayaan nasabahnya, termasuk rahasia perbankan yang melingkupi deposan dan simpanannya. Olehnya itu, transaksi ilegal sangat merugikan nasabah sebagai korban tindak pidana tersebut. Sehingga keamanan suatu sistem merupakan hal yang sangat penting dalam menjalankan aktifitas perdagangan di dunia virtual. ${ }^{6}$

Pada tahun 2018, telah terjadi kasus tindak pidana transaksi ilegal di Indonesia dengan cara skimming, sebagaimana berdasarkan Putusan Pengadilan Negeri Jakarta Pusat Nomor 313/Pid.B/2018/PN.Jkt.Pst. Kasus skimming tersebut dilakukan oleh Andrii Chystiakov selaku terdakwa I, Viktor Buiukli selaku terdakwa II, Denys Metelskyi selaku terdakwa III, dan Vlad selaku DPO. Kasus tersebut dilakukan di mesin ATM Indomaret KS Tubun Jakarta Pusat, dan mesin ATM BCA Jakarta, atau setidak-tidaknya pada suatu tempat yang masih termasuk dalam daerah hukum Pengadilan Negeri Jakarta Pusat. ${ }^{7}$ Awalnya, terjadi pertemuan antara Andrii Chystiakov dengan Vlad di Ukraina. Vlad menawarkan pekerjaan kepada Andrii Chystiakov untuk menarik uang menggunakan kartu yang akan diberikan Vlad kepadanya. Namun penarikan harus dilakukan di Indonesia, dan jika berhasil, Vlad akan mendapatkan 15\%. Vlad juga memerintahkan Andrii Chystiakov untuk mencari orang lain untuk melakukan pekerjaan serupa. ${ }^{8}$ Selanjutnya, para terdakwa melakukan penarikan berulang kali di beberapa ATM yang berbeda dengan menggunakan kartu ATM hasil kloning/skimming. Dari penarikan uang tersebut, kerugian Bank Mandiri sebesar Rp. 29.273.790,00 karena harus mengganti uang Anna Silalahi sebagai nasabah dan korban penggunaan kartu ATM hasil kloning tersebut. ${ }^{9}$ Dengan memperhatikan Pasal 363 ayat (1) butir 4 UU No. 1 Tahun 1960, para terdakwa terbukti secara sah dan meyakinkan bersalah melakukan tindak pidana "pencurian dengan pemberatan", Majelis Hakim menjatuhkan pidana penjara kepada masing-masing terdakwa selama empat tahun penjara serta uang tunai sebesar Rp. 20.000.000,00 dikembalikan kepada Ana Silalahi yang merupakan nasabah sebagai korban transaksi ilegal menggunakan kartu ATM milik orang lain. ${ }^{10}$

Kasus serupa juga terjadi pada tahun 2019, sebagaimana berdasarkan Putusan Pengadilan Negeri Mataram Nomor 778/Pid.Sus/2019/PN Mtr. Kasus skimming tersebut dilakukan oleh Georgiev Kaloyan Petrov Alias Michael. Kasus tersebut dilakukan di Mesin ATM Bank BNI di depan Hotel Ratih di Jl. Pejanggik No. 127 Cakranegara Kota Mataram. ${ }^{11}$ Awalnya, saksi Ardiyan Wicaksono selaku staf perencanaan dan pemantau PT. SSI Sentra Operasi Mataram yang berdasarkan pada sistem monitoring melihat adanya transaksi mencurigakan di mesin ATM Bank BNI Hotel Ratih. Transaksi di mesin ATM tersebut selalu sepi dan tiba-tiba terjadi lonjakan transaksi yang tinggi yaitu

\footnotetext{
${ }^{6}$ Editorial OJK. (2016). Pahami dan Hindari: Buku Memahami dan Menghindari Tindak Pidana Perbankan. Jakarta: Otoritas Jasa Keuangan, hlm. 24-25.

${ }^{7}$ Lihat Putusan PN Jakarta Pusat No. 313/Pid.B/2018/PN. Jkt. Pst, hlm. 4.

${ }^{8}$ Ibid., hlm. 4-5.

${ }^{9}$ Ibid., hlm. 5.

${ }^{10}$ Ibid., hlm. 27.

${ }^{11}$ Lihat Putusan PN Mataram No. 778/Pid.Sus/2019/PN Mtr, hlm. 3.
} 
sekitar Rp. 80.000.000,00 sampai dengan Rp. 100.000.000,00.12 Keesokan harinya, kembali terjadi transaksi yang mencurigakan di mesin ATM tersebut. Oleh karena itu, saksi Ardiyan Wicaksono bersama saksi Uwais Miftah Abdul Muis selaku wakil pimpinan PT. SSI Sentra Operasi Mataram dan saksi Waluyo Sugito dari Kepolisian Sektor Cakranegara selaku Petugas Pengawalan PT. SSI langsung mendatangi mesin ATM Bank BNI di Hotel Ratih dan menemukan Georgiev Kaloyan Petrov alias Michael sedang melakukan transaksi di mesin ATM tersebut. Waluyo Sugito lalu mengamankan dan meminta Georgiev Kaloyan Petrov alias Michael untuk mengeluarkan isi tasnya. Di tasnya, terdapat 17 kartu bertuliskan Room Access berwarna merah dengan masingmasing nomor 40 sampai dengan 56 yang digunakan untuk bertransaksi di mesin ATM dan 423 lembar uang pecahan Rp 100.000,00. ${ }^{13}$ Dari penarikan uang tersebut, maka Bank BNI adalah pihak yang dirugikan. ${ }^{14}$ Dengan memperhatikan Pasal 46 ayat (1) jo. Pasal 30 ayat (1) UU No. 19 Tahun 2016, menyatakan Georgiev Kaloyan Petrov alias Michael telah terbukti secara sah dan meyakinkan bersalah melakukan tindak pidana ITE "dengan sengaja dan tanpa hak atau melawan hukum mengakses komputer dan/atau sistem elektronik milik orang lain dengan cara apa pun", Majelis Hakim menjatuhkan pidana penjara kepada terdakwa Georgiev Kaloyan Petrov alias Michael dengan pidana penjara selama dua tahun dan denda sejumlah Rp. 200.000.000,00 Subsider dua bulan kurungan. ${ }^{15}$

Dari contoh Putusan Pengadilan di atas dan untuk melindungi nasabah dari tindak pidana transaksi ilegal, maka pihak perbankan melakukan perlindungan preventif. ${ }^{16}$ Perlindungan preventif dilakukan dengan selalu memperhatikan tingkat sistem keamanan yang diterapkan oleh PUJK. Adapun upaya hukum yang bisa diberikan kepada nasabah sebagai korban tindak pidana transaksi ilegal, sebagaimana berdasarkan Pasal 10 Peraturan Bank Indonesia Nomor 16/1/PBI/2014 tentang Perlindungan Konsumen Jasa Sistem Pembayaran (selanjutnya disebut PBI No. 16/1/PBI/2014), mengatur bahwa "Penyelenggara wajib bertanggung jawab kepada Konsumen atas kerugian yang timbul akibat kesalahan pengurus dan pegawai Penyelenggara".

Dari ketentuan di atas, dapat juga dipahami bahwa pertanggungjawaban PUJK berdasarkan asas tanggung jawab, yang terdiri dari: ${ }^{17}$

1. Tanggung jawab kontraktual;

2. Tanggung jawab produk;

3. Tanggung jawab profesional;

4. Tanggung jawab pidana.

\footnotetext{
${ }^{12}$ Ibid., hlm. 3.

${ }^{13}$ Ibid., hlm. 3-4.

${ }^{14}$ Ibid., hlm. 45.

${ }^{15}$ Ibid., hlm. 45-46

${ }^{16}$ Made Metu Dahana. (2012). Perlindungan Hukum dan Keamanan terhadap Wisatawan. Surabaya: Penerbit Paramita, hlm. 58.

${ }^{17}$ Edmon Makarim. (2019). Pengantar Hukum Telematika : Suatu Kompilasi Kajian. Jakarta: Rajawali Pres, hlm. 368-378.
} 
Berdasarkan uraian di atas, maka penelitian ini bertujuan untuk menguraikan penerapan hukum terhadap transaksi illegal menggunakan kartu ATM milik orang lain dan perlindungan hukum terhadap nasabah sebagai korban tindak pidana transaksi ilegal menggunakan kartu ATM hasil kloning. Adapun manfaat dalam penelitian ini ialah memberikan pemahaman kepada pihak Bank selaku PUJK dan juga Nasabah tentang pentingnya keamanan dalam layanan bertransaksi dengan menggunakan kartu ATM. Selain itu, bagi nasabah sebagai korban tindak pidana transaksi ilegal dapat mengetahui tata cara memperoleh perlindungan hukum sebagai konsumen.

\section{METODE}

Penelitian ini menggunakan pendekatan yuridis normatif, yakni penelitian yang dilakukan dengan menelaah teori-teori, konsep, asas hukum serta peraturan perundang-undangan. ${ }^{18}$ Jenis dan sumber bahan hukum terdiri dari:

1. Bahan hukum primer, yaitu bahan hukum yang bersumber dari peraturan perundang-undangan, catatan-catatan resmi, risalah dalam pembuatan peraturan perundang-undangan, serta putusan-putusan hakim. ${ }^{19}$ Adapun bahan hukum primer yang digunakan dalam penelitian ini, adalah sebagai berikut:

a. UU No. 1 Tahun 1960 tentang Perubahan Kitab Undang-Undang Hukum Pidana;

b. UU No. 8 Tahun 2010 tentang Pencegahan dan Pemberantasan Tindak Pidana Pencucian Uang;

c. UU No. 21 Tahun 2011 tentang Otoritas Jasa Keuangan;

d. UU No. 19 Tahun 2016 Perubahan Atas Undang-Undang Nomor 11 Tahun 2008 tentang Informasi dan Transaksi Elektronik;

e. PBI No. 16/1/PBI/2014 tentang Perlindungan Konsumen Jasa Sistem Pembayaran;

f. POJK No. 1/P0JK.07/2013 tentang Perlindungan Konsumen Sektor Jasa Keuangan;

g. POJK No. 18/POJK.07/2018 tentang Layanan Pengaduan Konsumen di Sektor Jasa Keuangan;

2. Bahan hukum sekunder, yaitu bahan hukum yang bersumber dari buku referensi dan artikel publikasi jurnal ilmiah yang berkaitan dengan penelitian ini.

3. Bahan hukum tersier, yaitu bahan hukum yang bersumber kamus hukum, makalah, atau data yang terdapat di internet yang berkaitan dengan penelitian ini.

Untuk memperoleh bahan hukum yang dibutuhkan dalam penelitian ini, maka digunakan teknik pengumpulan data studi kepustakaan, yakni menginventarisasi, membaca, dan menganalisis bahan-bahan hukum, baik bahan hukum primer, sekunder, maupun tersier. ${ }^{20}$

\footnotetext{
${ }^{18}$ Soerjono Soekanto \& Sri Mamudji. (2015). Penelitian Hukum Normatif: Suatu Tinjauan Singkat. Jakarta: PT. Raja Grafindo Persada, hlm. 13-14.

${ }^{19}$ Peter Mahmud Marzuki. (2011). Penelitian Hukum. Jakarta: Kencana Prenada Media Group, hlm. 141.

${ }^{20}$ Hasan Basri. (2021). Perlindungan Hukum terhadap Pelaku Tindak Pidana berdasarkan Sistem Peradilan Pidana Indonesia. SIGn Jurnal Hukum, CV. Social Politic Genius (SIGn), 2(2), hlm. 108.
} 
Bahan hukum yang telah terkumpul kemudian diolah secara deskriptif kualitatif. Adapun metode analisis dilakukan dengan cara mengidentifikasi secara sistematis, dipolarisasi, dikategorisasi dan dikelompokkan sesuai dengan alur pembahasan dalam penelitian ini. ${ }^{21}$

\section{HASIL DAN PEMBAHASAN}

\section{A. Penerapan Hukum terhadap Pelaku Tindak Pidana Transaksi Ilegal Menggunakan Kartu ATM Milik Orang Lain}

Transaksi ilegal merupakan perbuatan yang dilarang, sebagaimana berdasarkan UU No. 1 Tahun 1960 dan UU No. 19 Tahun 2016. Transaksi ilegal merupakan tindakan konvensional yang tidak asing lagi. Perbedaan satu-satunya terletak pada modus dan operator yang dilakukan dengan menggunakan fasilitas elektronik. Dalam upayanya, pelaku mengkloning kartu ATM tersebut untuk digunakan sebagaimana mestinya seperti kartu ATM yang diterbitkan oleh bank dan dengan mudah melakukan transaksi di mesin ATM. Kartu ATM hasil kloning dapat berupa discount card yang dibuat dengan menggunakan bahan plastik dan dicetak bersamaan dengan PIN ATM.

Transaksi ilegal juga dinilai sebagai aktifitas mencurigakan, sebagaimana berdasarkan Pasal 1 butir 5 Undang-Undang Republik Indonesia Nomor 8 Tahun 2010 tentang Pencegahan dan Pemberantasan Tindak Pidana Pencucian Uang, menjelaskan bahwa Transaksi Keuangan Mencurigakan adalah:

a. Transaksi Keuangan yang menyimpang dari profil, karakteristik, atau kebiasaan pola Transaksi dari Pengguna Jasa yang bersangkutan;

b. Transaksi Keuangan oleh Pengguna Jasa yang patut diduga dilakukan dengan tujuan untuk menghindari pelaporan Transaksi yang bersangkutan yang wajib dilakukan oleh Pihak Pelapor sesuai dengan ketentuan Undang-Undang ini;

c. Transaksi Keuangan yang dilakukan atau batal dilakukan dengan menggunakan Harta Kekayaan yang diduga berasal dari hasil tindak pidana; atau

d. Transaksi Keuangan yang diminta oleh PPATK untuk dilaporkan oleh Pihak Pelapor karena melibatkan harta kekayaan yang diduga berasal dari hasil tindak pidana.

\section{Penerapan UU No. 1 Tahun 1960 terhadap Pelaku Tindak Pidana Transaksi ilegal menggunakan kartu ATM Milik Orang Lain}

Unsur kesalahan pada pelaku tindak pidana transaksi ilegal relatif mudah ditemukan, karena transaksi ilegal hanya dapat dilakukan bagi pelaku yang mempunyai kemampuan di bidang teknologi. Dengan begitu, setiap pelaku yang ingin menarik uang di mesin ATM, terlebih dahulu mengkloning kartu ATM. Sehingga setiap tindak pidana transaksi ilegal menggunakan kartu ATM

${ }^{21}$ Nurul Qamar \& Farah Syah Rezah. (2020). Metode Penelitian Hukum: Doktrinal dan Non-Doktrinal. Makassar: CV. Social Politic Genius (SIGn), hlm. 9. 
milik orang lain pasti dilakukan secara sadar dan telah direncanakan. Para pelaku tindak pidana transaksi ilegal bertujuan untuk menguasai sebagian atau seluruh dana milik nasabah di bank yang memiliki sistem keamanan yang lemah atau mudah diretas. Berdasarkan Pasal 362 UU No. 1 Tahun 1960, mengatur bahwa:

"Barang siapa mengambil barang sesuatu, yang seluruhnya atau sebagian kepunyaan orang lain, dengan maksud untuk dimiliki secara melawan hukum, diancam karena pencurian, ... ."

Dari ketentuan di atas dapat dipahami bahwa terdiri dari suatu unsur antara lain:

1. Unsur Objektif meliputi:

a. Barang siapa mengambil;

b. Suatu barang;

c. Yang seluruhnya atau sebagian kepunyaan orang lain;

2. Unsur subjektif, meliputi:

a. Dengan maksud;

b. Untuk memiliki barang;

c. Secara melawan hukum.

Unsur barang siapa mengambil barang sesuatu, yang seluruhnya atau sebagian kepunyaan oranglain, harus dibuktikan dengan adanya perpindahan suatu barang kepada pelaku. Apabila dihubungkan dengan transaksi ilegal menggunakan kartu ATM milik orang lain, maka pelaku memiliki serta menguasai PIN dengan kartu ATM hasil kloning dan dapat dengan mudah melakukan transaksi penarikan uang. Modus yang dilakukan dalam transaksi ilegal perbankan yaitu pelaku memiliki serta menguasai PIN ATM tanpa seijin nasabah. Akibatnya tindak pidana ini menimbulkan kerugian materil dan immateril bagi nasabah, dan perbuatan tersebut dilakukan dengan cara melawan hukum.

Lebih lanjut, Berdasarkan Pasal 363 ayat (1) butir 4 UU No. 1 Tahun 1960, mengatur bahwa "pencurian yang dilakukan oleh dua orang atau lebih".

Dari ketentuan di atas, maka faktor ini dimaksudkan sebagai tindak pidana "pencurian dengan pemberatan", karena dua orang atau lebih bersekutu untuk mencapai tujuan yang diinginkan oleh pelaku kejahatan.

UU No. 1 Tahun 1960 sendiri tidak secara eksplisit mengatur cybercrime, karena perumusan peraturan perundang-undangan selalu melihat konteks dan kebutuhan masyarakatnya. Akan tetapi, sebagaimana menurut Moeljatno bahwa: ${ }^{22}$

"Tindak pidana merupakan perbuatan yang dilarang berdasarkan undang-undang, dan terdapat sanksi berupa pidana bagi yang melanggar larangan tersebut. Selain itu, ancaman pidana hanya ditunjukan pada perbuatan pelaku"

${ }^{22}$ M. Moeljatno. (2015). Asas-Asas Hukum Pidana. Jakarta: PT. Rineka Cipta, hlm. 1. 


\section{Penerapan Undang-Undang Informasi dan Elektronik terhadap Pelaku Tindak Pidana Transaksi Ilegal Menggunakan Kartu ATM Milik Orang Lain}

Selain diatur dalam tindak pidana pencurian dengan pemberatan berdasarkan UU No. 1 Tahun 1960, transaksi ilegal sebagaimana berdasarkan Pasal 30 UU No. 19 Tahun 2016, mengatur bahwa:

(1) Setiap Orang dengan sengaja dan tanpa hak atau melawan hukum mengakses Komputer dan/atau Sistem Elektronik milik Orang lain dengan cara apa pun.

(2) Setiap Orang dengan sengaja dan tanpa hak atau melawan hukum mengakses Komputer dan/atau Sistem Elektronik dengan cara apa pun dengan tujuan untuk memperoleh Informasi Elektronik dan/atau Dokumen Elektronik.

(3) Setiap Orang dengan sengaja dan tanpa hak atau melawan hukum mengakses Komputer dan/atau Sistem Elektronik dengan cara apa pun dengan melanggar, menerobos, melampaui, atau menjebol sistem pengamanan.

Dari ketentuan di atas, dapat ditegaskan sebagai regulasi dalam penerapan hukum tindak pidana transaksi ilegal menggunakan kartu ATM milik orang lain. $^{23}$

Selain itu, berdasarkan Pasal 1 butir 15 UU No. 19 Tahun 2016, menjelaskan bahwa "Akses adalah kegiatan melakukan interaksi dengan Sistem Elektronik yang berdiri sendiri atau dalam jaringan".

Kode akses yang terdapat pada transaksi ilegal menggunakan kartu ATM milik orang lain yaitu PIN ATM, sebagaimana berdasarkan Pasal 1 butir 16 UU No. 19 Tahun 2016, menjelaskan bahwa:

"Kode Akses adalah angka, huruf, simbol, karakter lainnya atau kombinasi di antaranya, yang merupakan kunci untuk dapat mengakses Komputer dan/atau Sistem Elektronik lainnya."

Sedangkan dalam kejahatan ini yang termasuk pada sistem elektronik adalah mesin ATM yang digunakan sebagai cara untuk mencapai atau memasuki suatu sistem elektronik dilakukan dengan cara ilegal. Mengakses suatu informasi kartu ATM milik orang lain tanpa izin dari nasabah merupakan suatu tindak pidana yang menitikberatkan pada perbuatan dan akibat yang ditimbulkan.

Adanya unsur musyawarah pada pelaku tindak pidana transaksi ilegal menggunakan kartu ATM milik orang lain untuk mendapatkan atau menguasai uang atau saldo di rekening ATM nasabah untuk kepentingan finansial pelaku. Modus yang dilakukan oleh pelaku adalah dengan mengkloning kartu, atau kartu tersebut dapat berupa kartu diskon atau dalam bentuk apapun yang

${ }^{23}$ Christin Dessy Natalia, A. A. Sagung Laksmi Dewi, \& I Made Minggu Widyantara. (2020). Sanksi Pidana terhadap Warga Negara Asing yang Melakukan Tindakan Pembobolan Anjungan Tunai Mandiri (ATM) dengan Teknik Skimming. Jurnal Preferensi Hukum, Universitas Warmadewa, 1(2), hlm. 40. 
mencantumkan PIN di bagian belakang kartu ATM untuk dapat melakukan transaksi ilegal.

Berikut contoh kasus tindak pidana transaksi ilegal di Singapura dengan menggunakan kartu ATM milik orang lain. Berdasarkan Putusan Pengadilan Tinggi Republik Singapura Nomor Kasus MA 112/2006 tentang Navaseelan Balasingam vs Jaksa Penuntut Umum. Dengan memperhatikan 10 dakwaan, antara lain sebagai berikut: ${ }^{24}$

(1) Lima dakwaan berdasarkan Pasal 4 Statuta Republik Singapura Nomor 19 Tahun 1993 tentang Undang-Undang Penyalahgunaan Komputer (selanjutnya disebutStatuta Singapura No.19 Tahun 1993), yaitu mengakses beberapa data dari mesin ATM yang disimpan di sistem komputer pusat UOB dengan maksud untuk melakukan pencurian uang; dan

(2) Lima dakwaan berdasarkan Pasal 379 Statuta Republik Singapura Nomor 4 Tahun 1871 tentang Hukum Pidana, terkait pencurian uang dari UOB melalui transaksi yang tidak sah.

Berdasarkan dakwaan terkait Statuta Singapura No. 19 Tahun 1993 di atas, Majelis Hakim menjatuhkan pidana penjara kepada terdakwa selama tujuh tahun enam bulan penjara. ${ }^{25}$

Lebih lanjut, tindak pidana transaksi ilegal di Jepang dengan menggunakan kartu ATM milik orang lain, sebagaimana berdasarkan Pasal 1 Undang-Undang Pemerintah Jepang Nomor 128 Tahun 1999 tentang Larangan Akses Komputer Tanpa Izin (selanjutnya disebut UU Pemerintah Jepang No. 128 Tahun 1999), menjelaskan bahwa:

"Maksud dari Undang-undang ini adalah untuk mencegah kejahatan terkait komputer yang dilakukan melalui jaringan telekomunikasi dan memelihara ketertiban terkait telekomunikasi yang diwujudkan melalui fitur kontrol akses dengan melarang tindakan akses komputer tanpa izin dan menetapkan sanksi untuk itu serta tindakan bantuan yang harus diambil oleh Komisi Keamanan Publik Nasional untuk mencegah terulangnya tindakan tersebut, dengan demikian memberikan kontribusi pada perkembangan yang baik dari masyarakat informasi dan telekomunikasi yang maju."

Dari ketentuan di atas, transaksi ilegal ini dilakukan dengan mengakses elektromagnetik informasi rekening bank. UU Pemerintah Jepang No. 128 Tahun 1999, juga mengatur akses masuk komputer yang tidak sah, yang salah satu efeknya akan menyebabkan kerusakan informasi yang berkaitan dengan keamanan nasional. ${ }^{26}$

${ }^{24}$ Lihat Putusan Pengadilan Tinggi Republik Singapura Nomor Kasus MA 112/2006, hlm. 1.

${ }^{25}$ Ibid., hlm. 10.

${ }^{26}$ Fawaz Abad Aldurra. (2013). "Cybercrime and Penal Code: A Comparative Study Between United Arab Emirates and Japan". Disertasi. Fukuoka University, Japan, hlm. 42-44. 
Merujuk pada penerapan hukum di Singapura dan Jepang, aturan tentang tindak pidana transaksi ilegal tidak menggunakan Kitab Undang-Undang Hukum Pidana di negara tersebut. Adapun ketentuan tindak pidana transaksi ilegal di Indonesia maupun Singapura dan Jepang, antara lain sebagai berikut.

\section{a. Indonesia}

Berdasarkan Pasal 46 UU No. 19 Tahun 2016, mengatur bahwa:

(1) Setiap Orang yang memenuhi unsur sebagaimana dimaksud dalam Pasal 30 ayat (1) dipidana dengan pidana penjara paling lama 6 (enam) tahun dan/atau denda paling banyak Rp. 600.000.000,00 (enam ratus juta rupiah).

(2) Setiap Orang yang memenuhi unsur sebagaimana dimaksud dalam Pasal 30 ayat (2) dipidana dengan pidana penjara paling lama 7 (tujuh) tahun dan/atau denda paling banyak Rp. 700.000.000,00 (tujuh ratus juta rupiah).

(3) Setiap Orang yang memenuhi unsur sebagaimana dimaksud dalam Pasal 30 ayat (3) dipidana dengan pidana penjara paling lama 8 (delapan) tahun dan/atau denda paling banyak Rp. 800.000.000,00 (delapan ratus juta rupiah).

Selain diatur berdasarkan UU No. 19 Tahun 2016, transaksi ilegal menggunakan kartu ATM milik orang lain juga diatur berdasarkan Pasal 363 ayat (1) butir 4 UU No. 1 Tahun 1960.

\section{b. Singapura}

Berdasarkan Pasal 4 Statuta Singapura No. 19 Tahun 1993, mengatur tentang "Akses dengan maksud untuk melakukan atau memfasilitasi terjadinya pelanggaran".

Berdasarkan Pasal 4 ayat (3) Statuta Singapura No. 19 Tahun 1993, mengatur bahwa:

"Setiap orang yang bersalah melakukan pelanggaran menurut pasal ini akan dikenakan hukuman denda tidak melebihi $\$ 50.000$ atau penjara untuk jangka waktu tidak lebih dari sepuluh tahun atau keduanya."

Berdasarkan Pasal 5 Statuta Singapura No. 19 Tahun 1993, mengatur tentang "Modifikasi materi komputer tanpa izin".

Berdasarkan Pasal 5 ayat (1) Statuta Singapura No. 19 Tahun 1993, mengatur bahwa:

"Barang siapa yang melakukan tindakan apa pun yang diketahuinya akan menyebabkan modifikasi yang tidak sah dari konten komputer mana pun akan bersalah atas pelanggaran dan akan dikenakan hukuman denda tidak melebihi \$10.000 atau 
penjara untuk jangka waktu tidak lebih dari tiga tahun atau keduanya, dan untuk hukuman kedua atau selanjutnya, akan dikenakan hukuman denda tidak melebihi \$20.000 atau penjara untuk jangka waktu tidak lebih dari lima tahun atau keduanya."

Berdasarkan Pasal 5 ayat (2) Statuta Singapura No. 19 Tahun 1993, mengatur bahwa:

"Jika ada kerusakan yang disebabkan sebagai akibat dari pelanggaran menurut pasal ini, seseorang yang dihukum karena pelanggaran tersebut dan akan dikenakan hukuman denda tidak melebihi \$50.000 atau penjara untuk jangka waktu tidak lebih dari tujuh tahun atau keduanya."

\section{c. Jepang}

Berdasarkan Pasal 3 UU Pemerintah Jepang No. 128 Tahun 1999, mengatur bahwa "Siapa pun dilarang untuk terlibat dalam Tindakan Akses Komputer Tanpa Izin".

Berdasarkan Pasal 4 UU Pemerintah Jepang No. 128 Tahun 1999, mengatur bahwa:

"Setiap orang dilarang memperoleh kode identifikasi orang lain yang terkait dengan Fitur Kontrol Akses untuk tujuan terlibat dalam Tindakan Akses Komputer Tanpa Izin."

Berdasarkan Pasal 5 UU Pemerintah Jepang No. 128 Tahun 1999, mengatur bahwa:

"Setiap orang dilarang, kecuali ada alasanyang dapat dibenarkan untuk menolak melakukannya atau alasan sah lainnya, untuk memberikan kode identifikasi orang lain yang terkait dengan Fitur Kontrol Akses kepada orang lain selain Administrator Akses yang terkait dengan Fitur Kontrol Akses yang bersangkutan dan Pengguna yang Sah yang memiliki kode identifikasi yang bersangkutan."

Berdasarkan Pasal 6 UU Pemerintah Jepang No. 128 Tahun 1999, mengatur bahwa:

"Dilarang bagi siapa pun untuk menyimpan kode identifikasi orang lain yang terkait dengan Fitur Kontrol Akses yang telah diperoleh secara salah untuk tujuan terlibat dalam Tindakan Akses Komputer Tanpa Izin."

Berdasarkan Pasal 11 UU Pemerintah Jepang No. 128 Tahun 1999, mengatur bahwa:

"Barang siapa yang melanggar ketentuan Pasal 3 akan dipidana penjara dengan masa kerja tidak lebih dari tiga tahun atau denda paling banyak ¥1.000.000." 
Berdasarkan Pasal 12 ayat (1), ayat (2), dan ayat (3) UU Pemerintah Jepang No. 128 Tahun 1999, mengatur bahwa setiap orang yang termasuk dalam salah satu item berikut akan dihukum penjara dengan pekerjaan tidak lebih dari satu tahun atau denda tidak lebih dari 500.000 yen.

i) Seseorang yang melanggar ketentuan Pasal 4;

ii) Seseorang yang telah memberikan kode identifikasi orang lain yang melanggar ketentuan Pasal 5 meskipun mengetahui bahwa penerima bermaksud menggunakannya untuk Tindakan Akses Komputer Tanpa Izin;

iii) Seseorang yang melanggar ketentuan Pasal 6.

\section{B. Perlindungan Hukum terhadap Nasabah Sebagai Korban Tindak Pidana Transaksi Ilegal}

Pada tahun 2018-2019 terjadi peningkatan kasus pembobolan rekening nasabah di beberapa bank dengan menggunakan kartu ATM hasil kloning. Misalnya di Jakarta Pusat dan Mataram, pelaku melakukan transaksi ilegal menggunakan kartu ATM milik orang.

Atas dasar kasus tersebut, pihak Bank menerima laporan dari nasabahnya karena pada saat nasabah hendak melakukan transaksi penarikan uang, mesin ATM tidak merespon dengan keterangan bahwa saldo tidak mencukupi. Sedangkan nasabah yakin bahwa saldo di rekeningnya masih mencukupi. Selain itu, polisi menyimpulkan dari hasil observasinya bahwa telah terjadi transaksi ilegal menggunakan kartu ATM hasil kloning. Oleh karena itu, saldo dari nasabah tersebut habis tanpa sepengetahuannya.

Tindak pidana transaksi ilegal menggunakan kartu ATM milik orang lain, dimana nantinya nasabah tidak mengetahui bahwa saldo di rekeningnya telah habis karena telah terjadi penarikan menggunakan kartu ATM hasil kloning. Seperti yang terjadi pada 2018 dan 2019 di Bank BNI, Bank Mandiri, dan Bank BCA yang saldo rekeningnya hilang hingga puluhan juta rupiah. Setelah melakukan pengaduan ke pihak Bank, ternyata nasabah telah melakukan transaksi penarikan uang di mesin ATM. Nasabah yang menjadi korban tindak pidana transaksi ilegal merasa tidak melakukan aktifitas penarikan uang tersebut. Oleh karena itu, perlindungan hukum yang dapat diberikan kepada nasabah terdiri dari dua cara, antara lain sebagai berikut. ${ }^{27}$

\section{Perlindungan Tidak Langsung}

Perlindungan preventif merupakan perlindungan tidak langsung yang dimana dapat meminimalkan kejahatan yang semakin sering terjadi di sektor

${ }^{27}$ Komang Juniawan. (2013). Perlindungan Hukum terhadap Nasabah Korban Kejahatan Penggandaan Kartu ATM pada Bank Swasta Nasional di Denpasar. Jurnal Magister Hukum Udayana (Udayana Master Law Journal), Universitas Udayana, 2(2), hlm. 7. 
perbankan. Bank dapat menggunakan chip pada kartu ATM sebagai langkah pengamanan. Kartu ATM dilengkapi dengan chip mengikuti National Standard Indonesian Chip Card Specification (NSICCS) yang ditetapkan oleh Bank Indonesia pada kartu ATM atau debit di Indonesia. Selain itu, Bank dapat secara berkala mengganti magnetic strip pada kartu ATM dengan teknologi chip implant. Tujuannya adalah untuk menyeimbangkan pengoperasian kartu ATM dengan standar internasional. Selain menggunakan teknologi chip implant, juga dilengkapi dengan One Time Password (OTP), sehingga akan semakin memperkuat keamanan kartu ATM.

Fungsi OTP adalah untuk menghindari tindak pidana transaksi ilegal menggunakan kartu ATM milik orang lain. Sistematika penggunaan OTP dalam melakukan transaksi yaitu OTP akan dikirimkan ke nomor ponsel Nasabah. ${ }^{28}$ Jika OTP berhasil diverifikasi oleh mesin ATM, maka hanya nasabah yang dapat melakukan transaksi tunai dengan menentukan jumlah uang yang akan ditarik tunai. ${ }^{29}$ Jika nasabah kehilangan kartu ATM, siapa pun yang menemukan kartu tersebut tidak dapat menggunakannya karena harus ada OTP untuk melakukan transaksi. ${ }^{30}$ Oleh karena itu, pengamanan OTP dapat menghindari kode yang jatuh pada pihak yang tidak bertanggung jawab dan dapat merugikan nasabah.

Dengan demikian, perbankan di Indonesia dapat memberikan informasi mengenai manajemen risiko dengan menggunakan teknologi informasi terkait penggantian kartu ATM dengan teknologi chip implant. Nasabah dalam melakukan transaksi keuangan juga harus memperhatikan atau memilih lokasi ATM agar aman dari tindak kejahatan. Olehnya itu, kartu ATM dengan teknologi chip implant dan juga diperkuat dengan adanya OTP sebagai autentikasi dua faktor (two-factor authentication), maka risiko tindak pidana transaksi ilegal menggunakan kartu ATM milik orang lain dapat diminimalisir.

\section{Perlindungan Secara Langsung}

Nasabah sebagai korban dapat mengajukan pengaduan ke Bank. Selain Bank, ada lembaga yang bertugas melakukan pengawasan yaitu Otoritas Jasa Keuangan (OJK). Berdasarkan Pasal 2 huruf d Peraturan Otoritas Jasa Keuangan Nomor 1/P0JK.07/2013 tentang Perlindungan Konsumen Sektor Jasa Keuangan, mengatur bahwa "Perlindungan Konsumen menerapkan prinsip kerahasiaan dan keamanan data/informasi Konsumen".

Apabila nasabah merasa dirugikan, sebagaimana berdasarkan Pasal 1 butir 6 Peraturan Otoritas Jasa Keuangan Nomor 18/P0JK.07/2018 tentang Layanan Pengaduan Konsumen di Sektor Jasa Keuangan (selanjutnya disebut POJK No.

\footnotetext{
${ }^{28}$ Mohsin Karovaliya, et al. (2015). Enhanced Security for ATM Machine with OTP and Facial Recognition Features. Procedia Computer Science, Elsevier, 45, hlm. 391.

${ }^{29}$ Ibid.

${ }^{30}$ K. Sudharsan, et al. (2019). Two Three Step Authentication in ATM Machine to Transfer Money and for Voting Application. Procedia Computer Science, Elsevier, 165, hlm. 305.
} 
18/P0JK.07/2018), menjelaskan bahwa:

"Pengaduan adalah ungkapan ketidakpuasan Konsumen baik lisan atau tertulis yang disebabkan oleh adanya kerugian dan/atau potensi kerugian materiil, wajar dan secara langsung pada Konsumen karena tidak dipenuhinya perjanjian dan/atau dokumen transaksi keuangan yang telah disepakati."

Berdasarkan Pasal 1 butir 7 POJK No. 18/POJK.07/2018, menjelaskan bahwa:

"Layanan Pengaduan adalah layanan yang disediakan oleh PUJK untuk mengupayakan penyelesaian Pengaduan di sektor jasa keuangan."

Dengan adanya pengaduan nasabah atas transaksi yang mencurigakan, maka pihak Bank selaku PUJK akan menindaklanjuti pengaduan nasabah tersebut. Jika belum ada tanggapan dari waktu yang diberikan dari Perbankan, sebagai nasabah dapat mengajukan pengaduan ke OJK selaku lembaga pengawas keuangan. Berdasarkan Pasal 7 huruf c Undang-Undang Nomor 21 Tahun 2011 tentang Otoritas Jasa Keuangan (selanjutnya disebut UU No. 21 Tahun 2011), mengatur bahwa untuk melaksanakan tugas pengaturan dan pengawasan di sektor Perbankan ..., OJK mempunyai wewenang pengaturan dan pengawasan mengenai aspek kehati-hatian bank, meliputi:

1. manajemen risiko;

2. tata kelola bank;

3. prinsip mengenal nasabah dan anti pencucian uang; dan

4. pencegahan pembiayaan terorisme dan kejahatan perbankan.

Dengan demikian, sebagaimana berdasarkan Pasal 29 UU No. 21 Tahun 2011, mengatur bahwa OJK melakukan pelayanan pengaduan Konsumen yang meliputi:

a. menyiapkan perangkat yang memadai untuk pelayanan pengaduan Konsumen yang dirugikan oleh pelaku di Lembaga Jasa Keuangan;

b. membuat mekanisme pengaduan Konsumen yang dirugikan oleh pelaku di Lembaga Jasa Keuangan; dan

c. memfasilitasi penyelesaian pengaduan Konsumen yang dirugikan oleh pelaku di Lembaga Jasa Keuangan sesuai dengan peraturan perundangundangan di sektor jasa keuangan.

Nasabah bisa memperoleh ganti kerugian dari Bank. Ganti kerugian dilakukan secara perdata berdasarkan perjanjian antara pihak Bank dengan nasabah, sebagaimana berdasarkan Pasal 10 PBI No. 16/1/PBI/2014, mengatur bahwa:

"Penyelenggara wajib bertanggung jawab kepada Konsumen atas kerugian yang timbul akibat kesalahan pengurus dan pegawai Penyelenggara." 
Menurut Edmon Makarim, bahwa: ${ }^{31}$

"Bentuk pertanggungjawaban PUJK secara keperdataan mengacu pada dasar hubungan kontrak (contractual liability) atau perdata secara langsung dari PUJK kepada nasabah yang dirugikan."

Penggantian kerugian secara perdata bagi nasabah sebagai korban tindak pidana transaksi ilegal menggunakan kartu ATM hasil kloning dilakukan dengan mengajukan pengaduan ke Bank mengenai fakta bahwa saldo rekeningnya telah berkurang. ${ }^{32}$ Selanjutnya, pihak Bank akan menyelidiki riwayat transaksi berdasarkan nomor rekening nasabah untuk mengetahui kapan dan di mana terjadinya transaksi ilegal menggunakan kartu ATM milik orang lain. ${ }^{33}$

Tindakan bank sebagai langkah perlindungan yang diberikan kepada nasabah, salah satunya yaitu dengan meningkatkan keamanan di setiap mesin ATM agar bisa memantau transaksi dengan menggunakan kartu ATM. Jika terjadi transaksi yang mencurigakan, pihak Bank dapat segera mengambil tindakan dan menginformasikan kepada nasabah mengenai transaksi ilegal menggunakan kartu ATM hasil kloning. Dengan demikian, nasabah sebagai konsumen akan terlindungi dari transaksi ilegal, khususnya segera mengganti kartu ATM dengan teknologi chip implant dan dilengkapi OTP pada saat melakukan transaksi keuangan.

\section{KESIMPULAN DAN SARAN}

Berdasarkan uraian hasil dan pembahasan, maka dapat disimpulkan bahwa penerapan hukum terhadap transaksi illegal menggunakan kartu ATM milik orang lain, diatur dalam UU No. 1 Tahun 1960 dengan kualifikasi tindak pidana "pencurian dengan pemberatan". Sedangkan dalam UU No. 19 Tahun 2016 dengan kualifikasi tindak pidana "dengan sengaja dan tanpa hak atau melawan hukum mengakses komputer dan/ atau sistem elektronik milik orang lain dengan cara apa pun". Modus yang dilakukan oleh pelaku tindak pidana transaksi illegal menggunakan kartu ATM milik orang lain, adalah dengan cara mengkloning atau memalsukan kartu ATM milik orang lain. Tindak pidana transaksi illegal menggunakan kartu ATM milik orang lain, belum diatur secara tegas di Indonesia apabila dibandingkan dengan Singapura dan Jepang. Kedua negara tersebut telah membentuk secara khusus peraturan perundang-undangan tentang Tindak pidana transaksi illegal. Adapun perlindungan hukum terhadap nasabah sebagai korban tindak pidana transaksi ilegal menggunakan kartu ATM hasil kloning, dapat diketahui berdasarkan beberapa peraturan perundang-undangan, antara lain UU No. 21 Tahun 2011, PBI No. 16/1/PBI/2014, POJK No. 1/POJK.07/2013, serta

\footnotetext{
${ }^{31}$ Edmon Makarim. (2003). Kompilasi Hukum Telematika. Jakarta: PT. Raja Grafindo Persada, hlm. 8.

${ }^{32}$ Aryani Witasari \& Aris Setiono. (2015). Perlindungan Hukum Pengguna Jasa Electronic Banking (E-Banking) Ditinjau dari Perspektif Hukum Pidana di Indonesia. Jurnal Pembaharuan Hukum, Universitas Unissula, 2(1), hlm. 129.

${ }^{33}$ Dian Ekawati. (2018). Perlindungan Hukum terhadap Nasabah Bank yang Dirugikan Akibat Kejahatan Skimming Ditinjau dari Perspektif Teknologi Informasi dan Perbankan. Unes Law Review, Universitas Ekasakti Padang, 2(2), hlm. 168.
} 
POJK No. 18/POJK.07/2018. Selain berdasarkan peraturan perundang-undangan, Bank selaku PUJK dapat memberikan perlindungan secara tidak langsung kepada nasabahnya dengan cara mengganti secara berkala mengganti magnetic strip pada kartu ATM dengan teknologi chip implant dan juga diperkuat dengan adanya OTP sebagai autentikasi dua faktor (two-factor authentication), sehingga risiko tindak pidana transaksi ilegal menggunakan kartu ATM milik orang lain dapat diminimalisir. Dengan dasar kesimpulan tersebut, diharapkan secara tegas untuk dibentuk UndangUndang tentang tindak pidana transaksi ilegal. Selain itu, Bank selaku PUJK harus membuat kebijakan penggunaan kartu ATM dengan teknologi chip implant, serta penerapan OTP kepada para nasabahnya.

\section{REFERENSI}

Antonius Maria Laot Kian. (2015). Tindak Pidana Credit/Debit Card Fraud dan Penerapan Sanksi Pidananya dalam Hukum Pidana Indonesia. Hasanuddin Law Review (e-Journal), Universitas Hasanuddin, 1(1), hlm. 47-60. doi: http://dx.doi. org/10.20956/halrev.v1i1.39

Aryani Witasari \& Aris Setiono. (2015). Perlindungan Hukum Pengguna Jasa Electronic Banking (E-Banking) Ditinjau dari Perspektif Hukum Pidana di Indonesia. Jurnal Pembaharuan Hukum, Universitas Unissula, 2(1), hlm. 126-137. doi: http:// dx.doi.org/10.26532/jph.v2i1.1422

Budi Triandi. (2019). Keamanan Informasi Secara Aksiologi dalam Menghadapi Era Revolusi Industri 4.0. JURIKOM (Jurnal Riset Komputer), Universitas Budi Darma, 6(5), hlm. 477-483.

Christin Dessy Natalia., A. A. Sagung Laksmi Dewi., \& I Made Minggu Widyantara. (2020). Sanksi Pidana terhadap Warga Negara Asing yang Melakukan Tindakan Pembobolan Anjungan Tunai Mandiri (ATM) dengan Teknik Skimming. Jurnal Preferensi Hukum, Universitas Warmadewa, 1(2), hlm. 37-41. doi: https://doi. org/10.22225/jph.1.2.2340.37-41

Danrivanto Budhijanto. (2019). Cyberlaw dan Revolusi Industri 4.0. Bandung: Logoz Publishing.

Dian Ekawati. (2018). Perlindungan Hukum terhadap Nasabah Bank yang Dirugikan Akibat Kejahatan Skimming Ditinjau dari Perspektif Teknologi Informasi dan Perbankan. Unes Law Review, Universitas Ekasakti Padang, 2(2), hlm. 157-171. doi: https://doi.org/10.31933/law.v1i2.24

Editorial OJK. (2016). Pahami dan Hindari: Buku Memahami dan Menghindari Tindak Pidana Perbankan. Jakarta: Otoritas Jasa Keuangan.

Edmon Makarim. (2003). Kompilasi Hukum Telematika. Jakarta: PT. Raja Grafindo Persada.

Edmon Makarim. (2019). Pengantar Hukum Telematika : Suatu Kompilasi Kajian. Jakarta: Rajawali Pres.

Fawaz Abad Aldurra. (2013). "Cybercrime and Penal Code: A Comparative Study Between United Arab Emirates and Japan”. Disertasi. Fukuoka University, Japan. 
Hasan Basri. (2021). Perlindungan Hukum terhadap Pelaku Tindak Pidana berdasarkan Sistem Peradilan Pidana Indonesia. SIGn Jurnal Hukum, CV. Social Politic Genius (SIGn), 2(2), hlm. 104-121. doi: https://doi.org/10.37276/sjh.v2i2.90

K. Sudharsan, et al. (2019). Two Three Step Authentication in ATM Machine to Transfer Money and for Voting Application. Procedia Computer Science, Elsevier, 165, hlm. 300-306. doi: https://doi.org/10.1016/j.procs.2020.01.046

Komang Juniawan. (2013). Perlindungan Hukum terhadap Nasabah Korban Kejahatan Penggandaan Kartu ATM pada Bank Swasta Nasional di Denpasar. Jurnal Magister Hukum Udayana (Udayana Master Law Journal), Universitas Udayana, 2(2), hlm. $1-20$.

M. Moeljatno. (2015). Asas-Asas Hukum Pidana. Jakarta: PT. Rineka Cipta.

Made Metu Dahana. (2012). Perlindungan Hukum dan Keamanan terhadap Wisatawan. Surabaya: Penerbit Paramita.

Mohsin Karovaliya, et al. (2015). Enhanced Security for ATM Machine with OTP and Facial Recognition Features. Procedia Computer Science, Elsevier, 45, hlm. 390396. doi: https://doi.org/10.1016/j.procs.2015.03.166

Nevita Sari. (2019). Perlindungan Hukum Bagi Konsumen Nasabah dalam Card Skimming (Studi Kasus Bank BNI Syariah Pusat di Jakarta). Reformasi Hukum, Universitas Islam Jakarta, 23(2), hlm. 149-168. doi: https://doi.org/10.46257/ jrh.v23i2.93

Ni Nyoman Muryatini. (2016). Perlindungan Hukum Bagi Nasabah Pengguna Anjungan Tunai Mandiri (ATM) dalam Sistem Perbankan di Indonesia. Jurnal Magister Hukum Udayana (Udayana Master Law Journal), Universitas Udayana, 5(1), hlm. 119-130.

Nurul Qamar \& Farah Syah Rezah. (2020). Metode Penelitian Hukum: Doktrinal dan Non-Doktrinal. Makassar: CV. Social Politic Genius (SIGn).

Peraturan Bank Indonesia Nomor 11/11/PBI/2009 tentang Penyelenggaraan Kegiatan Alat Pembayaran dengan Menggunakan Kartu. (Lembaran Negara Republik Indonesia Tahun 2009 Nomor 64 DASP. Tambahan Lembaran Negara Republik Indonesia Nomor 5000).

Peraturan Bank Indonesia Nomor 14/2/PBI/2012 tentang Perubahan Atas Peraturan Bank Indonesia Nomor 11/11/PBI/2009 tentang Penyelenggaraan Kegiatan Alat Pembayaran dengan Menggunakan Kartu. (Lembaran Negara Republik Indonesia Tahun 2012 Nomor 11 DASP. Tambahan Lembaran Negara Republik Indonesia Nomor 5275).

Peraturan Bank Indonesia Nomor 16/1/PBI/2014 tentang Perlindungan Konsumen Jasa Sistem Pembayaran. (Lembaran Negara Republik Indonesia Tahun 2014 Nomor 10 DKSP. Tambahan Lembaran Negara Republik Indonesia Nomor 5498).

Peraturan Otoritas Jasa Keuangan Nomor 1/P0JK.07/2013 tentang Perlindungan Konsumen Sektor Jasa Keuangan. (Lembaran Negara Republik Indonesia Tahun 2013 Nomor 118. Tambahan Lembaran Negara Republik Indonesia Nomor 5431). 
Peraturan Otoritas Jasa Keuangan Nomor 18/P0JK.07/2018 tentang Layanan Pengaduan Konsumen di Sektor Jasa Keuangan. (Lembaran Negara Republik Indonesia Tahun 2018 Nomor 151. Tambahan Lembaran Negara Republik Indonesia Nomor 6246).

Peter Mahmud Marzuki. (2011). Penelitian Hukum. Jakarta: Kencana Prenada Media Group.

Putusan Pengadilan Negeri Jakarta Pusat Nomor 313/Pid.B/2018/PN.Jkt.Pst.

Putusan Pengadilan Negeri Mataram Nomor 778/Pid.Sus/2019/PN Mtr

Putusan Pengadilan Tinggi Republik Singapura Nomor Kasus MA 112/2006.

Soerjono Soekanto \& Sri Mamudji. (2015). Penelitian Hukum Normatif: Suatu Tinjauan Singkat. Jakarta: PT. Raja Grafindo Persada.

Statuta Republik Singapura Nomor 4 Tahun 1871 tentang Hukum Pidana.

Statuta Republik Singapura Nomor 19 Tahun 1993 tentang Undang-Undang Penyalahgunaan Komputer.

Undang-Undang Pemerintah Jepang Nomor 128 Tahun 1999 tentang Larangan Akses Komputer Tanpa Izin.

Undang-Undang Republik Indonesia Nomor 1 Tahun 1946 tentang Peraturan Hukum Pidana.

Undang-Undang Republik Indonesia Nomor 1 Tahun 1960 tentang Perubahan Kitab Undang-Undang Hukum Pidana. (Lembaran Negara Republik Indonesia Tahun 1960 Nomor 1. Tambahan Lembaran Negara Republik Indonesia Nomor 1921).

Undang-Undang Republik Indonesia Nomor 11 Tahun 2008 tentang Informasi dan Transaksi Elektronik. (Lembaran Negara Republik Indonesia Tahun 2008 Nomor 58. Tambahan Lembaran Negara Republik Indonesia Nomor 4843).

Undang-Undang Republik Indonesia Nomor 8 Tahun 2010 tentang Pencegahan dan Pemberantasan Tindak Pidana Pencucian Uang. (Lembaran Negara Republik Indonesia Tahun 2010 Nomor 122. Tambahan Lembaran Negara Republik Indonesia Nomor 5164).

Undang-Undang Republik Indonesia Nomor 21 Tahun 2011 tentang Otoritas Jasa Keuangan. (Lembaran Negara Republik Indonesia Tahun 2011 Nomor 111. Tambahan Lembaran Negara Republik Indonesia Nomor 5253).

Undang-Undang Republik Indonesia Nomor 19 Tahun 2016 tentang Perubahan Atas Undang-Undang Nomor 11 Tahun 2008 tentang Informasi dan Transaksi Elektronik. (Lembaran Negara Republik Indonesia Tahun 2016 Nomor 251. Tambahan Lembaran Negara Republik Indonesia Nomor 5952).

\footnotetext{
I Fina Agustina Suhyana., Sigid Suseno., \& Tasya Safiranita Ramli. (2021). Transaksi I

I Ilegal Menggunakan Kartu ATM Milik Orang Lain. SIGn Jurnal Hukum, CV. Social Politic ! I Genius (SIGn), 2(2), hlm. 138-156. doi: https://doi.org/10.37276/sjh.v2i2.92
} 